Recommended by Doctor of Pharmacy, professor V. I. Chueshov

UDC 615.32:339.13.021:616-095

DOI: $10.24959 /$ nphj.17.2157

K. V. Tolochko, L. I. Vyshnevska

National University of Pharmacy

\title{
Analysis of the domestic pharmaceutical market of anthelmintic medicines
}

The problem of helminthiases is particularly relevant not only in veterinary medicine, but also in medical practice of mankind. Today, the spread of parasitic diseases concerns any country in the world, including countries with high living standards. The greatest danger is the fact that the vast majority of cases of the digestive system helminthiases is in children of the preschool and early school age. In all age groups of patients there is also a significant deterioration of the immune system and development of autoimmune diseases as a consequence of the disease.

Aim. To analyze the range of anthelmintic medicines presented at the pharmaceutical market of Ukraine.

Materials and methods. Distribution of anthelmintic medicines by their origin and dosage forms, as well as by price offers was studied at the level of the industrial area of Kharkiv and the Kharkiv region. The data processing was performed using the methods of economic and statistical analysis, and the results were processed using computer programs.

Results and discussion. The domestic market of anthelmintic medicines offers 19 medicines on the basis of praziquantel, mebendazole, albendazole, piperazine, pyrantel, levamisole and one medicine in the form of a herbal tea - tansy flowers. Medicines of the Ukrainian production are only $36.8 \%$, while the most $(63.2 \%)$ of medicinal products comes from manufacturers of the UK, France and India. Anthelmintic medicines are presented in 3 dosage forms, among them coated tablets dominate. The analysis of price offers on the example of those that are available in Kharkiv and the Kharkiv region, taking into account the offers of internet pharmacies, showed their significant variation (from 2 to 1248). Among the medicines with albendazole as the active ingredient the greatest difference of price offers is typical for vormil in the form of coated tablets.

Conclusions. It has been found that the existing range of anthelmintic medicines requires development and implementation of new domestic products in the industrial production. A particular attention should be paid to development of products based on the medicinal plant raw material.

Key words: pharmaceutical market; market research; medicines; helminthiases

К. В. Толочко, Л.І.Вишневська

\section{Аналіз вітчизняного фармацевтичного ринку протигельмінтних лікарських препаратів}

Проблема ураження гельмінтозами є особливо актуальною не тільки у ветеринарній медицині, але і у медичній практиці людства. Розповсюдженість паразитарних хвороб стосується кожної країни світу, зокрема країн з високим рівнем життя. Найбільшу небезпеку становить той факт, що переважна більшість випадків захворювання на гельмінтози системи травлення відноситься до дітей дошкільного та молодшого шкільного віку. Також у всіх вікових груп пацієнтів відмічається значне погіршення стану імунної системи, а також розвиток аутоімунних захворювань як наслідок перенесеної хвороби.

Мета роботи - аналіз асортименту протигельмінтних лікарських препаратів, представлених на фрармацевтичному ринку України.

Матеріали та методи. Досліджували розподіл протигельмінтних лікарських препаратів за походженням та лікарськими формами, а також за ціновими пропозиціями на останні на рівні промислового регіону Харкова та Харківської області. Обробку даних проводили з використанням методів економіко-статистичного аналізу з обробкою результатів за допомогою комп'ютерних програм.

Результати та їх обговорення. Вітчизняний ринок протигельмінтних лікарських препаратів представлений 19 лікарськими препаратами на основі празиквантелу, мебендазолу, альбендазолу, піперазину, пірантелу, левамізолу і одним препаратом у формі фіточаю - квітками пижмо. Вітчизняні препарати складають лише 36,8 \%, тоді як більшість (63,2%) лікарських препаратів надходить від виробників з Великої Британії, Франції та Індії. Протигельмінтні лікарські препарати представлені у 3-х лікарських фрормах, серед яких домінують таблетки, вкриті оболонкою. Аналіз цінових пропозицій на прикладі тих, що є доступними у Харкові та Харківській області, враховуючи пропозиції інтернет-аптек, показав значний їх розбіг (від 2 до 1248). Серед лікарських препаратів, діючою речовиною яких $є$ альбендазол, найвища різниця цінових пропозицій характерна для вормілу у формі таблеток, вкритих оболонкою.

Висновки. Встановлено, що існуючий асортимент протигельмінтних лікарських засобів потребує розробки та впровадження у промислове виробництво нових вітчизняних препаратів. Особливу увагу доцільно приділити розробці препаратів на основі лікарської рослинної сировини.

Ключові слова: фрармацевтичний ринок; дослідження ринку; лікарські препарати; гельмінтози 


\section{Е. В. Толочко, Л. И. Вишневская}

\section{Анализ отечественного фармацевтического рынка противогельминтных лекарственных препаратов}

Проблема поражения гельминтозами является особенно актуальной не только в ветеринарной медицине, но и в медицинской практике человечества. На сегодняшний день распространение паразитарных болезней касается каждой страны мира, в т. ч. стран с высоким уровнем жизни. Наибольшую опасность представляет тот факт, что подавляющее большинство случаев заболевания гельминтозами пищеварительной системы относится к детям дошкольного и младшего школьного возраста. Также во всех возрастных группах пациентов отмечается значительное ухудшение состояния иммунной системы, а также развитие аутоиммунных заболеваний как следствие перенесенной болезни.

Цель работы - анализ ассортимента противогельминтных лекарственных препаратов, представленных на фрармацевтическом рынке Украины.

Материалы и методы. Исследовали распределение противогельминтных лекарственных препаратов по происхождению и лекарственным формам, а также по ценовым предложениям на последние на уровне промышленного региона Харькова и Харьковской области. Обработку данных проводили с использованием методов экономико-статистического анализа с обработкой результатов с помощью компьютерных программ.

Результаты и их обсуждение. Отечественный рынок противогельминтных лекарственных препаратов представлен 19 лекарственными препаратами на основе празиквантела, мебендазола, альбендазола, пиперазина, пирантела, левамизола и одним препаратом в фрорме фиточая - цветками пижмы. Отечественные препараты составляют лишь 36,8 \%, тогда как большинство (63,2 \%) лекарственных препаратов поступает от производителей из Великобритании, Франции и Индии. Противогельминтные лекарственные препараты представлены в 3-х лекарственных формах, среди которых доминируют таблетки, покрытые оболочкой. Анализ ценовых предложений на примере тех, которые доступны в Харькове и Харьковской области, учитывая предложения интернет-аптек, показал их значительный разбег (от 2 до 1248). Среди лекарственных препаратов, действующим веществом которых является альбендазол, самая высокая разница ценовых предложений характерна для вормила в фрорме таблеток, покрытых оболочкой.

Выводы. Установлено, что существующий ассортимент противогельминтных лекарственных препаратов требует разработки и внедрения в промышленное производство новых отечественных препаратов. Особое внимание целесообразно уделить разработке препаратов на основе лекарственного растительного сырья.

Ключевые слова: фрармацевтический рынок; исследование рынка; лекарственные препараты; гельминтозы

According to statistics of the World Health Organization from 16 to 50 million people die annually because of infectious and parasitic diseases. By the prevalence helminth infestations take the second place after tuberculosis. Out of 150 of the world's species of helminths approximately 30 of them can be found in Ukraine (enterobiosis is about $75 \%$, ascariasis $-20 \%$ ) $[1,2]$.

The results of the current studies of the problem stated have shown that the presence of this group of diseases is closely associated with the body's immunological reactions. Thus, the study of the epidemiological picture and a number of animal studies indicate association of helminthiases with autoimmune disorders, including inflammatory diseases of the gastrointestinal tract, diabetes, etc. [3, 4].

Currently, the study of the patient's immune system status helps to assess not only the general state of health and identify potential complications of the disease occurrence, but also determine the pathogen. A specific indicator of helminths is a sharp increase in antibodies of $\operatorname{IgE}$ class and eosinophils $[5,6,7]$.

The domestic pharmaceutical market of anthelmintic medicines is represented with derivatives of praziquantel, mebendazole, albendazole, piperazine, pyrantel, levamisole, and one herbal medicine - tansy flowers $[8,9]$.

The aim of our study is to analyze the domestic pharmaceutical market of anthelmintic medicines by their origin at the place of production, dosage forms, in which they enter the market and price offers on medicines at pharmacies on the example of Kharkiv and the Kharkiv region.

\section{Materials and Methods}

The range of anthelmintic medicines was studied by the origin and dosage forms. The study of price offers was conducted based on the data given on the site http:// medbrowse.com.ua/ for Kharkiv and the Kharkiv region, including price offers of internet-pharmacies with the delivery service from the other regions of Ukraine (as of January, 18, 2017).

The data processing was performed using the methods of economic and statistical analysis, and the results were processed using computer programs $[10,11]$.

\section{Results and Discussion}

The analysis of the existing range of anthelmintic medicines (Fig. 1) by their origin (Tab. 1,2) showed that most of them were produced abroad. The study of dosage forms (Fig. 2) demonstrated that medicines in the form of tablets prevailed.

Price offers for decaris (Tab. 3) dominated. The results of the further analysis of price offers obtained for medicines based on albendazole are given in Tab. 4, Fig. 3.

According to the ATC-classification anthelmintic medicines are divided into products used in trematodosis (P02B) and products used in nematodosis (P02C) (Fig. 1).

According to the compendium the group of anthelminthic medicines includes 19 names (Tab. 1).

It was found that among the available anthelmintic medicines those of foreign origin $(63.2 \%)$ dominated, while the Ukrainian manufacturers offered fewer medicines $(36.8 \%)$. 


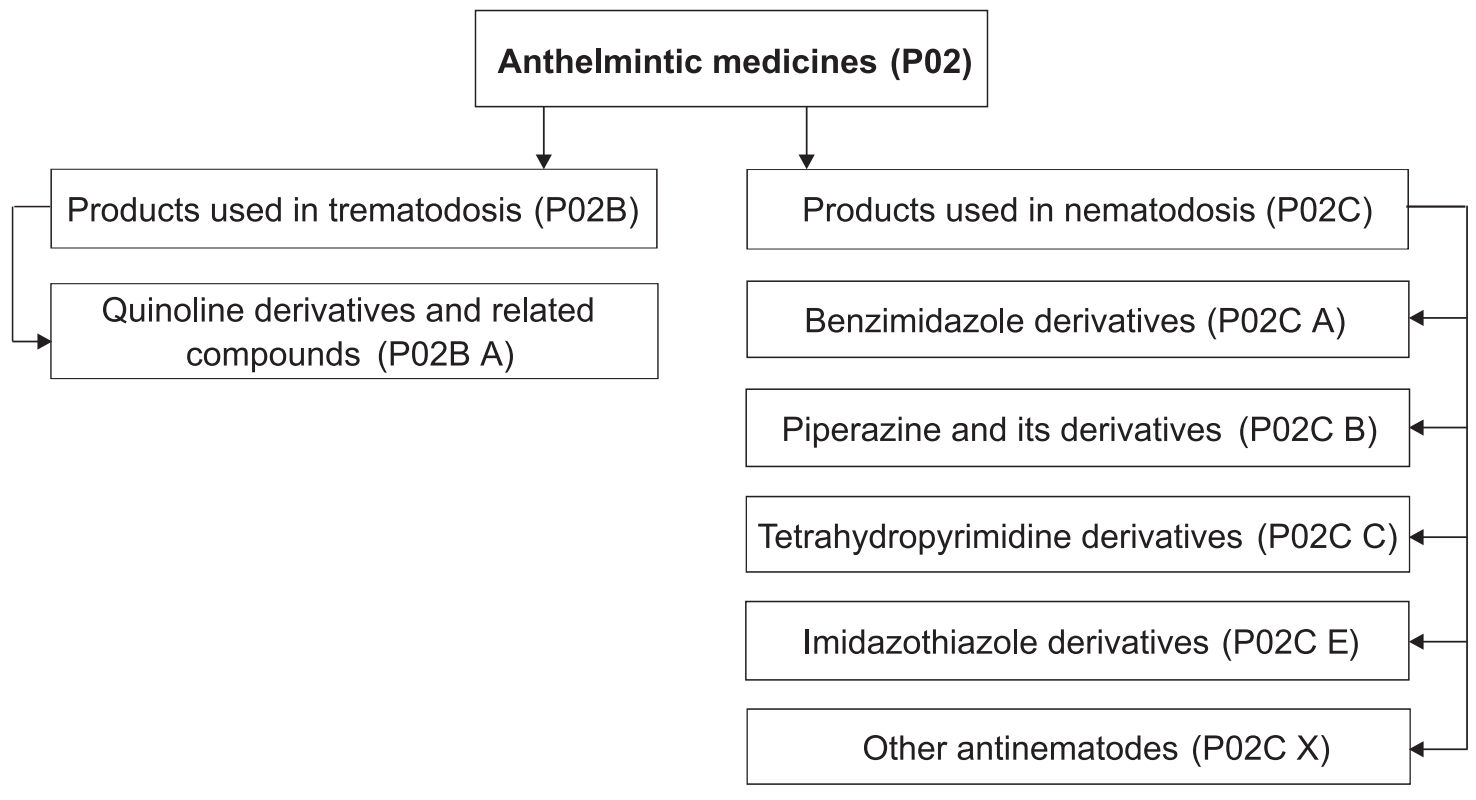

Fig. 1. The ATC-classification of anthelmintic medicines

Distribution of medicines by the countries-producers is shown in Tab. 2.

As seen from the results obtained, medicines from the UK $(25.0 \%$ ), France and India (each for $16.5 \%$ ) are on the top of the list.
Dosage forms of anthelmintic medicines at the domestic pharmaceutical market are presented in Fig. 2. The results show that coated tablets $(60.90 \%)$ and oral suspensions (34.80\%) prevail, while the share of medicines in the form of herbal tea is insignificant $(4.30 \%)$.

Table 1

Anthelmintic medicines ${ }^{*}$

\begin{tabular}{|c|c|c|c|c|}
\hline $\begin{array}{c}\text { Active } \\
\text { ingredient }\end{array}$ & ATC & Trade name & Manufacturer (country) & Dosage form \\
\hline \multicolumn{5}{|c|}{ Products used in trematodosis } \\
\hline Praziquantel & P02B A01 & Biltricide ${ }^{\circledR}$ & Bayer Pharma (Germany) & Coated tablets \\
\hline \multicolumn{5}{|c|}{ Products used in nematodosis } \\
\hline \multirow{2}{*}{ Mebendazole } & \multirow{2}{*}{ P02B A01 } & Vermox & Gedeon Richter (Romania) & Coated tablets \\
\hline & & Vermox ${ }^{\circledR}$ & Janssen - Silah SpA (Italy) & Coated tablets \\
\hline \multirow{6}{*}{ Albendazole } & \multirow{6}{*}{ P02B A03 } & Albela & Kusum Pharm (Ukraine) & Coated tablets \\
\hline & & Aldazol & Kyiv Vitamin Factory (Ukraine) & Coated tablets \\
\hline & & Zente $^{\mathrm{TM}}$ & GlaxoSmithKline (France) & Coated tablets, suspension \\
\hline & & Zentel $^{\mathrm{TM}}$ & GlaxoSmithKline (Export) (the UK) & Coated tablets, suspension \\
\hline & & Albenzole & M. Biotech Ltd.(the UK) & Coated tablets \\
\hline & & Vormil & Mili Healthcare (the UK) & Coated tablets, suspension \\
\hline Piperazine & P02C B01 & $\begin{array}{c}\text { Piperazine adipate- } \\
\text { Darnitsya }\end{array}$ & PrAT Darnitsya (Ukraine) & Coated tablets, suspension \\
\hline \multirow{6}{*}{ Pyrantel } & \multirow{6}{*}{ P02C C01 } & Helmintox & Lab. Innotech International (France) & Coated tablets, suspension \\
\hline & & Pyrantel & Kusum Pharm (Ukraine) & Suspension \\
\hline & & Pyrantel Polfarma & Medana Pharma S. A. (Poland) & Suspension \\
\hline & & Pyrantel suspension & Kusum Healthcare (India) & Suspension \\
\hline & & Pyrantel tablets & Kusum Healthcare (India) & Coated tablets \\
\hline & & Pyrantel-VISHPHA & LLC"DCT"Pharmaceutical Factory (Ukraine) & Suspension \\
\hline \multirow[b]{2}{*}{ Levamisole } & \multirow[b]{2}{*}{ P02C E01 } & Decaris & Gedeon Richter (Hungary) & Coated tablets \\
\hline & & Levamizol-Zdorovia & $\begin{array}{l}\text { "Zdorovia" Ltd. Pharmaceutical } \\
\text { company (Ukraine) }\end{array}$ & Coated tablets \\
\hline Other & $\mathrm{P} 02 \mathrm{C} \times 10^{* *}$ & Tansy flowers & PrAT Liktravy (Ukraine) & Herbal tea \\
\hline
\end{tabular}

*Notes: the given list of medicines was made based on the compendium. Biologically active and dietary supplements were not included in the list of the medicines studied. 
Distribution of anthelmintic medicines of foreign production by the countries-producers

\begin{tabular}{|l|c|}
\hline \multicolumn{1}{|c|}{ Country-producer } & $\begin{array}{c}\text { The share at the domestic } \\
\text { pharmaceutical market, } \%\end{array}$ \\
\hline The United Kingdom & 25.0 \\
\hline France & 16.5 \\
\hline India & 16.5 \\
\hline Germany & 8.4 \\
\hline Romania & 8.4 \\
\hline Italy & 8.4 \\
\hline Poland & 8.4 \\
\hline Hungary & 8.4 \\
\hline Total & 100.0 \\
\hline
\end{tabular}

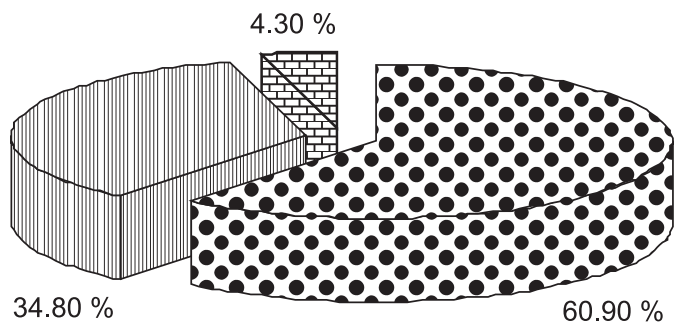

9 Coated tablets 四 Suspension 圖 Herbal tea

Fig. 2. Distribution of anthelmintic medicines by dosage forms

Since the offers for domestic and foreign medicines usually come from several distributors, it is reasonable to study the relevant price offers as the price of an offer significantly affects the availability of therapy for patients.

The general number of price offers for anthelmintic medicines as of January 18, 2017, is given in Tab. 3.

As seen from Tab. 3, the largest number of offers is for such anthelmintic medicines as decaris (1248), helmintox (699) and aldazol (653). The least number of price offers is for biltricide (6) and pyrantel tablets (2).

The results of the comparative analysis of price offers for medicines based on albendazole derivatives are listed in Tab. 4.

Fig. 3 shows that the greatest difference of maximum and minimal price offers is typical for vormil tablets (23.38) and zentel suspension (20.66). The smallest difference of price offers is for albela No.1 (2.33).
Price offers for anthelmintic medicines which are available in Kharkiv and the Kharkiv region

\begin{tabular}{|c|c|}
\hline Name & The number of offers \\
\hline Dekaris & 1248 \\
\hline Helmintox & 699 \\
\hline Aldazol & 653 \\
\hline Albela & 479 \\
\hline Vormil & 433 \\
\hline Pyrantel & 381 \\
\hline Zentel $^{\mathrm{TM}}$ (GlaxoSmithKline) & 368 \\
\hline Vermox ${ }^{\circledR}$ (Janssen - Silah) & 356 \\
\hline Levamisole-Health & 354 \\
\hline Pyrantel-VISHPHA & 323 \\
\hline Vermox (Gedeon Richter) & 257 \\
\hline Albenzol & 217 \\
\hline Tansy flowers & 52 \\
\hline Pyrantel Polfarma & 30 \\
\hline Piperazine adipate-Darnitsya & 26 \\
\hline Zentel $^{\mathrm{TM}}$ (GlaxoSmithKlineExport) & 22 \\
\hline Pyrantel suspension & 16 \\
\hline Biltricide ${ }^{\circledR}$ & 6 \\
\hline Pyrantel tablets & 2 \\
\hline
\end{tabular}

Table 4

The results of the comparative analysis of price offers for medicines based on albendazole

\begin{tabular}{|c|c|c|c|c|}
\hline \multirow{2}{*}{$\begin{array}{c}\text { Name and } \\
\text { dosage form }\end{array}$} & \multicolumn{4}{|c|}{ Price offer, UAH } \\
\cline { 2 - 5 } & $\min$ & $\max$ & $\begin{array}{c}\text { Average } \\
(\overline{\mathrm{x}})\end{array}$ & $\begin{array}{c}\text { Difference } \\
\left(\overline{\mathrm{x}}-\overline{\mathrm{x}}_{\mathrm{c}}\right)\end{array}$ \\
\hline Albela, No. 1 & 11.57 & 13.90 & 11.97 & -32.09 \\
\hline Albela, No. 3 & 32.49 & 41.70 & 37.04 & -7.02 \\
\hline Aldazol & 42.31 & 56.82 & 47.88 & +3.82 \\
\hline Vormil, tabl. & 68.30 & 91.68 & 74.25 & +30.19 \\
\hline Vormil, susp. & 47.30 & 63.63 & 54.86 & +10.80 \\
\hline Zentel, tabl. & 28.40 & 37.90 & 33.91 & -10.15 \\
\hline Zentel, susp. & 41.91 & 62.57 & 47.34 & +3.28 \\
\hline \multicolumn{5}{|c}{$\overline{\mathrm{x}}_{\mathrm{c}}=43.89$} \\
\hline
\end{tabular}

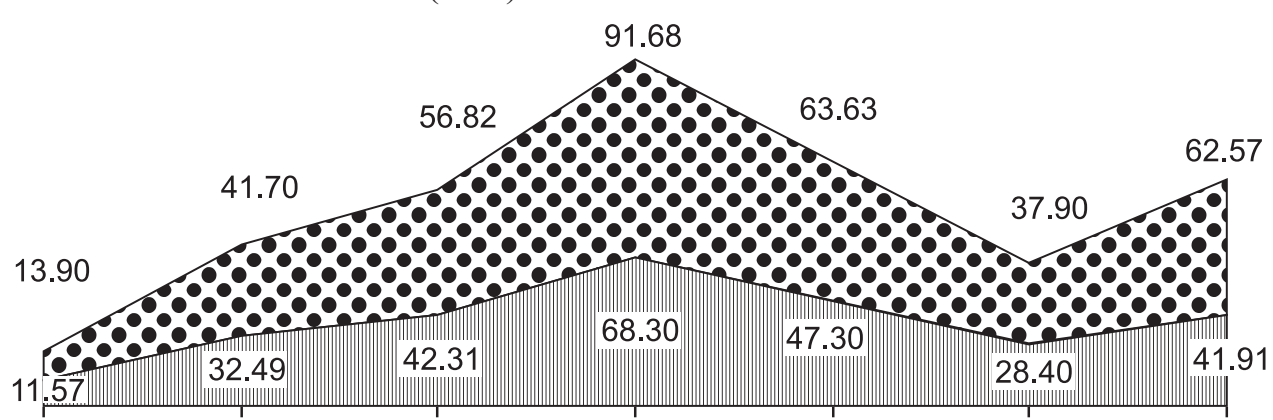

Albela, N. 1 Albela, N. 3 Aldazol Vormil, tabl. Vormil, susp. Zentel, tabl. Zentel, susp.

Maximum price $\quad$ Minimal price

Fig. 3. The minimal and maximum price offers for anthelmintic medicines based on albendazole 


\section{CONCLUSIONS}

The domestic market of anthelmintic medicines has been analyzed. It has been found that medicines of foreign production prevail. Among the suppliers from abroad manufacturers from the UK, India and France dominate. At the domestic pharmaceutical market anthelmintic medicines are presented in 3 dosage forms, among them coated tablets dominate.

The number of price offers that are available in Kharkiv and the Kharkiv region taking into account the offers of internet pharmacies has been studied. It has been determined that the maximum number of price offers is for decaris (1248), while the minimal quantity - for pyrantel tablets (2).

The analysis of price offers for anthelminthic medicines based on albendazole has been conducted. According to the results it has been found that the greatest difference of price offers is typical for vormil in the form of coated tablets (23.38) and zentel in the form of a suspension (20.66). The smallest difference of price offers is for albela No.1 (2.33).

Conflicts of Interest: authors have no conflict of interest to declare.

\section{REFERENCES}

1. Abbas, A. Diagnosis and recommended treatment of helminth infections / A. Abbas, W. Newsholme // Prescriber. - 2011. - Vol. 22, Issue 19. - P. 56-64. doi : 10.1002/psb.814.

2. Clinical guidelines. Diagnosis and treatment manual / I. Broek, N. Harris, M. Henkens et al. - 2013 ed. - Médecins Sans Frontières, 2013. - P. 334.

3. Deepak, T. The Role of Helminths in Immunity / T. Deepak, K. Goyal // J. of Allergy and Therapy. - 2016. - Vol. 7, Issue 1. - P. $231-232$. doi : 10.4172/2155-6121.1000231.

4. Van Riet, E. Chronic helminth infections induce immunomodulation: consequences and mechanisms / E. Van Riet, F. C. Hartgers, M. Yazdanbakhsh // Immunobiol. - 2007. - Vol. 212, Issue 6. - P. 475-490. doi : 10.1016/j.imbio.2007.03.009.

5. Tolochko, K. V. The basic approaches to pharmacotherapy of helminthiases and prospects of phytomedicines development for their treatment / K. V. Tolochko, L. I. Vishnevska // Clinical Pharmacy. - 2016. - T. 20, Vol. 4. - P. 4-10.

6. Standard Treatment Guidelines / Ministry of Health. - 6-th ed. - Ghana National Drugs Programme: GNDP, 2010. - P. 375-501.

7. Сршова, І. Б. Гельмінтози у дітей / І. Б. Сршова, Л. М. Осичнюк, Г. О. Мочалова // Перинатол. и педиатрия. - 2013. - № 2 (54). C. $125-131$.

8. Довідник лікарських засобів України [Електронний ресурс] : МОЗ України, Деп. фармац. діяльності. - К. : Інфодиск, 2004.

9. Компендиум. Лекарственные препараты [Електронний ресурс]. - Режим доступу : http://compendium.com.ua/

10. Статистика : підруч. / С. С. Герасименко, А. В. Головач, А. М. Єріна та ін.; під наук. ред. С. С. Герасименка. - 2-е вид., перероб. і доп. - К. : КНЕУ, 2000. - 467 c.

11. Теорія статистики : навч. посібник / Г. І. Мостовий, А. О. Дігтяр, В. К. Гаркавий та ін. - Х. : Магістр, 2002. - 300 с.

\section{REFERENCES}

1. Abbas, A., Newsholme, W. (2011). Diagnosis and recommended treatment of helminth infections. Prescriber, 22 (19), 56-64. doi: 10.1002/psb.814

2. Broek, I., Harris, N., Henkens, M., Mekaoui, H., Palma, P., Szumilin, E., Grouzard, V. (2013). Clinical guidelines. Diagnosis and treatment manual. (2013 ed.). Médecins Sans Frontières, 334.

3. Deepak,T., Goyal, K. (2016). The Role of Helminths in Immunity. Journal of Allergy and Therapy, 7 (1), 231-232. doi: 10.4172/2155-6121.1000231.

4. Van Riet, E., Hartgers, F. C., Yazdanbakhsh, M. (2007). Chronic helminth infections induce immunomodulation: Consequences and mechanisms. Immunobiology, 212 (6), 475-490. doi: 10.1016/j.imbio.2007.03.009

5. Tolochko, K. V., Vishnevska, L. I. (2016). The basic approaches to pharmacotherapy of helminthiases and prospects of phytomedicines development for their treatment. Clinical pharmacy, 20 (4), 4-10.

6. Ministry of Health. (2010). Standard Treatment Guidelines. (6-th ed.). Ghana National Drugs Programme: GNDP, $375-501$.

7. Yershova, I. B., Osychniuk, L. M., Mochalova, G. O. (2013). Perinatologiia i pediatriia, 2 (54), 125-131.

8. MOZ Ukrainy, Dep. far mats. Diialnosti. (2004). Dovidnyk likarskyh zasobiv Ukrainy. Kyiv: Infodis.

9. Kompendium. Lekarstvennye preparaty. (2017). Available at: http://compendium.com.ua/

10. Gerasimenko, S. S., Golovach, A. V., Erina, A. M. et al. (2000). Statystyka. Kyiv: KNEU, 467.

11. Mostovii, G. I., Digtiar, A. O., Garkavii, V. K. et al. (2002). Teoriia statystyki. Kharkiv: Magistr, 300.

Information about authors:

Tolochko K. V., Candidate of Pharmacy (Ph.D.), associate professor of the Department of Pharmaceutical Technology of Drugs, National University of Pharmacy.

E-mail: tolochko.kv@gmail.com

Vishnevska L. I., Doctor of Pharmacy (Dr. habil.), professor of the Department of Pharmaceutical Technology of Drugs, National University of Pharmacy

Відомості про авторів:

Толочко К. В., канд. фарм. наук, доцент кафедри аптечної технології ліків, Національний фармацевтичний університет. E-mail: tolochko.kv@gmail.com

Вишневська Л. І., д-р фарм. наук, професор кафедри аптечної технології ліків, Національний фармацевтичний університет

Сведения об авторах:

Толочко Е. В., канд. фарм. наук, доцент кафедры аптечной технологии лекарств, Национальный фармацевтический университет.

E-mail: tolochko.kv@gmail.com

Вишневская Л. И., Д-р фарм. наук, профессор кафедры аптечной технологии лекарств, Национальный фармацевтический университет 